\title{
COLORADOSCHOOLOFMINES
}

EARTH・ENERGY•ENVIRONMENT

Division of ECONOMICS AND BUSINESS

WORKING PAPER SERIES

\section{The Terms Of Trade Debate and the Policy Implications for Primary Product Producers}

\author{
John E. Tilton
}

\author{
Working Paper 2012-11 \\ http://econbus.mines . edu/working-papers/wp201211.pdf \\ Colorado School of Mines \\ Division of Economics and Business \\ 1500 Illinois Street \\ Golden, CO 80401
}

September 2012

(C) 2012 by the listed author(s). All rights reserved. 
Colorado School of Mines

Division of Economics and Business

Working Paper No. 2012-11

September 2012

Title:

The Terms Of Trade Debate and the Policy Implications for Primary Product Producers

Author(s):

John E. Tilton

Division of Economics and Business

Colorado School of Mines

and

Department of Mining Engineering

School of Engineering

Pontificia Universidad Católica de Chile

jtilton@mines.edu

\begin{abstract}
The terms of trade debate initiated by Raul Prebisch and Hans Singer over 60 years ago continues to this day and is unlikely to be resolved soon. However, even if Prebisch and Singer are right and the terms of trade of countries exporting primary products are falling, to suggest that these countries should diversify away from the production of mineral commodities and other primary products, as many have done, may be poor policy advice, encouraging countries to abandon a promising source of wealth with which to foster economic development.

This is because the prices of most goods are correlated with their production costs. If the prices of primary products are falling but a country's production costs are falling more, the profits, producer surplus, and wealth that the country realizes are rising, increasing the benefits it reaps from its primary product production and trade. Alternatively, when prices are rising but a country's costs are rising faster, the benefits it enjoys are falling notwithstanding higher primary product prices.

While it has long been recognized that falling costs can conceivably offset the adverse effects of lower prices and declining terms of trade for primary product producers, much of the available literature either ignores this likely possibility or contends in fact changes in relative product prices do not reflect changes in their production costs
\end{abstract}

$J E L$ codes: F13, L7, O24, Q1-4

Keywords: Terms of trade debate, Prebisch Singer thesis, resource curse, natural resource wealth and economic development; primary product prices and production costs. 
The Classical economists - Thomas Malthus, David Ricardo, and othersbelieved that the terms of trade of primary products would rise over time as the limited availability of land and other natural resources pushed their marginal production costs and prices up. In the early 1950s, Prebisch (1950) and Singer (1950) challenged this position, first by claiming that the terms of trade of primary products had fallen over time, and second by advancing several reasons for expecting this downward trend to continue.

In particular, they pointed out that the competitiveness of primary product markets means that the benefits of new, cost-reducing technology are passed on to consumers fully and quickly in the form of lower prices. With manufactured products, in contrast, the managers, owners, and employees of the producing firms are able to retain a good part of the benefits of technological change thanks to their market power. So, less of these benefits are passed on to consumers in the form of lower prices.

In addition, they argued, the long-run demand for primary products is less responsive (or elastic) with respect to income than is the demand for manufactured products. As a result, as income grows over time, the demand for manufactured products and in turn their prices rise more rapidly than is the case for primary products.

The Prebisch and Singer articles ignited a debate that spanned the second half of the $20^{\text {th }}$ century and continues to this day. As Hadass and Williamson (2002) note, the debate encompasses three questions: First, have the terms of trade of primary products in fact declined over the long run? This is the question on which most of the literature focuses. Second, what are the important determinants behind the observed changes in terms of trade? And third, what are the implications for public policy, especially for developing countries that depend on primary commodity exports?

With respect to the implications for public policy, it is fair to say that the work of Prebisch and Singer provided much of the intellectual support for the interventionist policies that many developing countries pursued during the 1950s, 1960s, and 1970s. These policies used protectionism and import substitution to promote domestic manufacturing and economic diversification with generally disappointing results. More recently, proponents of the resource curse thesis - which contends that reliance on the production of mineral and other primary products impedes economic growth in developing countries - have suggested that the declining terms of trade of primary products provides part of the explanation for this perverse result. ${ }^{2}$

While a comprehensive survey of the terms of trade literature is beyond the scope of this short study, the sections that follow examine each of the three questions noted

\footnotetext{
${ }^{2}$ The literature, it should be noted, also contains other explanations for the alleged curse of resources, as well as many studies questioning the existence of a negative association between resource dependence and economic development. For a review of this literature, see Stevens (2003) and Davis and Tilton (2005).
} 
above. The objective is to show that, although the debate continues, whether the long-run trend in the terms of trade of primary products is falling, stationary, or rising has by itself little or no policy significance for countries exporting primary products. Even if their terms of trade are falling, for many countries exporting primary products is still a promising development strategy, one that creates wealth and resources that they can use to promote economic growth.

\section{Trends in the Terms of Trade}

The Prebisch Singer hypothesis has generated a plethora of empirical studies testing whether or not the terms of trade of primary products have fallen. Only a few of the more important studies are noted here, as this is sufficient to demonstrate the diversity of views. More comprehensive surveys can be found in Spraos (1980), Diakosavvas and Scandizzo (1991), Hadass and Williamson (2002), and Cuddington and others (2007).

Spraos (1980), after reviewing the early literature, focuses on the difficulties and complexities encountered by these works. From his own analysis, he contends the evidence is inconclusive. However, Sapsford (1985), using the same data but a different specification of the relationship between the terms of trade and time, discovers a significant downward trend, and so provides more support for the Prebisch Singer hypothesis.

Bleaney and Greenaway (1993) analyze a new and improved data series for primary product prices from the World Bank (Grilli and Yang 1988). They find a significant downward trend in the terms of trade when data before 1925 (when primary product prices were quite high) are considered. But, when the period analyzed starts after 1925 , this is not the case. They also note that the prices for food, metals, and other groups of primary products behaved differently, suggesting that support for the Prebisch Singer hypothesis based on primary commodity prices in general may suffer from aggregation problems and thus be misleading. Cuddington (1992) provides further support for this concern. He examines price trends for 24 individual commodities, and finds that the longrun trends for all but three are zero or positive. However, using different estimation techniques on the same data, León and Soto (1997) find 17 of the 24 commodities have negative long-run price trends, a finding that provides much more support for the Prebisch Singer hypothesis.

More recently, Cuddington and others (2007), using techniques that allow the data to determine the unit root process and possible breaks in trends, conclude that the preponderance of the evidence suggests a single break in the data in 1921 with no drift, positive or negative, either before or after that date. Harvey and others (2010), using new time-series techniques and a new data set for 25 commodities covering the $17^{\text {th }}$ to $21^{\text {st }}$ centuries, identify a significant downward long-run trend in prices for 11 of their commodities. Fernandez (2012) finds that the empirical support for the Prebisch Singer hypothesis varies depending on the deflator employed, the time frequency of the data 
(monthly versus annual), and the choice of currency. For example, she finds more support for the hypothesis when prices are expressed in British pounds rather than U.S. dollars.

While most of the empirical studies assessing trends in terms of trade employ univariate time series analysis, Bloch and Sapsford (1991, 1996, 1997, and 2000) in a series of studies develop and estimate a multiple equation model that distinguishes between the primary commodity and manufacturing sectors. Their results, which can identify the influence of various contributing factors, provide support for a secular decline in the terms of trade of primary products.

One potentially important issue raised by Svedberg and Tilton (2006), which the available literature has yet to address, concerns the influence of quality improvements over time on the prices for primary products and manufactured goods. For some time, macroeconomists have known that the U.S. Consumer Price Index (CPI) and other deflators used to convert nominal prices into real prices tend to overestimate inflation. An important reason for this is their failure to adjust properly for improvements in the quality of products. A cell phone purchased today, for example, may be 10 percent cheaper as well as smaller and in other ways better than a similar model purchased a year ago. So, holding quality constant, the true decline in price is greater than 10 percent. The failure to take full account of such quality improvements across all goods and services introduces an upward bias in the CPI and other deflators. ${ }^{3}$

While the quality of the copper, coffee, and other primary products sold on international markets has improved over time, there are good reasons to suspect that such improvements have been modest compared to the quality improvements enjoyed by manufactured goods. This raises the possibility that some of the trend in the terms of trade of primary products simply reflects the fact that the quality of the goods exchanged for primary products is rising faster than the quality of primary products. When Svedberg and Tilton (2006) calculate the real price of copper using adjusted deflators designed to remove this bias, they find that the long-run trend over the past century is upward, not downward as is the case with the uncorrected deflators.

In summary, some but only some of the available data show that the terms of trade of primary products have fallen over the past century. It is also unclear whether breaks and changes in the long-run trend have occurred, and if so, whether a downward trend has prevailed in the recent past and continues to prevail today. Another important issue is the extent to which trends in the terms of trade of individual primary products or subgroups of primary products are captured by the trend for primary products as a whole. Most countries exporting primary products depend largely on only one or a few such products. Finally, the literature on the terms of trade for primary products has yet to assess the extent to which the observed trend simply reflects greater improvements in quality for manufactured goods.

\footnotetext{
${ }^{3}$ There are other reasons as well for believing common deflators are biased upward. For more on the sources and estimated magnitude of these biases, see Boskin and others (1998) and Schultze (2003).
} 


\section{Determinants of the Terms of Trade}

The terms of trade of primary product producing countries reflect changes over time in the prices of their exports (primary products) relative to the prices of their imports (manufactured and other goods). These changes in prices in turn are the result of shifts in product supply and demand curves. There are, however, good reasons to believe that the influence on prices of supply and demand varies both over the short and long runs and within the short run with economic conditions.

In the short run (a period of time insufficient to add significant new capacity), according to microeconomics the supply curve for a competitive industry should follow closely its short-run marginal cost curve. So as output increases we expect the supply curve to rise. It may also shift upward or downward as a result of changes in production costs. However, as long as capacity remains fixed, the supply curve should turn upward and become quite steep (more or less vertical) as output approaches the available capacity.

When the economy is booming and the demand curve intersects the supply curve in its steep or vertical segment, price varies largely or entirely in response to changes in demand. Figure 1 illustrates this situation. When demand is strong and the demand curve is $\mathrm{DD}_{1}$, the supply curve can shift from $\mathrm{SS}_{1}$ to $\mathrm{SS}_{2}$ (or vice versa) with little or no effect on the market equilibrium price. On the other had, when the demand curve shifts-from $\mathrm{DD}_{1}$ to $\mathrm{DD}_{2}$, for example - the market price does change.

When the economy is depressed and the demand curve intersects the supply curve where the latter's slope is rising more modestly, shifts in production costs and the supply curve can cause price to change. This situation is shown in Figure 1 with the demand curve $\mathrm{DD}_{3}$.

So in the short run when the economy is booming, cause and effect runs largely from changes in demand to prices. Changes in prices, then, may very well affect costs and in turn supply. When prices rise, for example, firms will hire new and less experienced workers to expand their output. Managers will be less concerned about containing costs than in maximizing output. For such reasons, costs are likely to rise, causing the supply curve to shift upward. Conversely, when the economy is depressed, cause and effect may run in both directions. Weak demand and low prices create strong incentives for firms to reduce costs, which when successful shift the supply curve down, causing prices to decline even more.

This suggests that whether cause and effect runs mostly from prices to costs or costs to prices in the short run is an empirical question. Recently students in a graduate seminar I give at the Colorado School of Mines and at the Catholic University of Chile have attempted to estimate whether prices Granger cause costs or costs Granger cause prices in the case of copper production (Flores and others 2011; McAllister and others 2011). While the results are quite preliminary, they provide evidence that over the short 
run (that is, from one year to the next) changes in prices are largely responsible for changes in costs, not vice versa.

What is important for our purposes here, however, is the fact that annual fluctuations in prices and costs are correlated: when prices go up costs rise, and when prices go down costs fall.

Shifting focus from the short to the long run (a period of time sufficient to add substantial new capacity), we know from microeconomics that the supply curve for a competitive industry tracks its long-run (rather than short-run) marginal cost curve. For most primary products, this curve rises with output but at a declining rate due to the greater availability of marginal resources. For example, the most fertile land for growing coffee is scarce compared to somewhat less attractive, though still suitable, land. Similarly, much less copper is found in deposits with an ore grade averaging 1.0 percent than in deposits with only 0.5 percent copper. As a result, the slope of the long-run supply curve becomes increasingly flat or horizontal as price rises (Tilton 1992).

For manufacture goods, the quality of resources being exploited is not an issue, and so, unless the availability of inputs is in some other way constrained over the long run, increases in output are possible with little or no effect on per unit costs. For example, automobile manufacturers, if given sufficient time to increase their own capacity and to induce their suppliers to do so as well, presumably could double their output without a significant increase in the cost per vehicle. As with primary products, constant or almost constant marginal costs imply a relatively flat supply curve.

A flat long-run supply curve has important implications. In particular, it means demand has little or no influence on the long-run equilibrium price. In Figure 2, for example, whether demand is $\mathrm{DD}_{1}$ or $\mathrm{DD}_{2}$, the long-run market price is more or less $\mathrm{P}^{*}$. This suggests that concerns over the long-run responsiveness of demand to changes in income for primary products are misplaced. If world GDP grows over the long run at 2.0 percent a year causing the demand for wheat and copper to rise by 0.5 percent and the demand for automobiles and personal computers to rise by 6.0 percent a year, the impact of this differential on the prices for primary products and manufactured goods is negligible if their long-run supply curves are relatively horizontal.

A horizontal supply curve also means that changes in long-run prices are largely or entirely driven by shifts in the supply curve. Such shifts occur because the costs of labor and other inputs change and because new technology reduces production costs. If we control for general inflation by examining trends in real costs and prices, the costreducing effects of new technology for most goods have over the long run offset any tendency for input prices to rise. As a result, the real prices of many primary products and manufactured goods have fallen over the long run. ${ }^{4}$

\footnotetext{
${ }^{4}$ For many primary products, the cost-reducing effects of new technology has produced a downward trend in real prices over the long run despite the need to exploit resources whose poorer quality entails higher costs. For more on the effects of depletion and technology on the long-run trends of real prices for mineral commodities, see Tilton (2003).
} 
There are, of course, exceptions, especially in the service sector. Where goods and services are heavily labor intensive and new technology is unable to reduce significantly the man-hours needed per unit of output, the rise in real wages over time tends to push prices higher. Education, medical care, legal services, and haircuts are examples. But even in such cases, it is changing costs that are largely or entirely driving the long-run trends in prices.

So far our examination of the determinants of prices and terms of trade has assumed that markets are competitive. As noted earlier, however, Prebisch and Singer argue that the markets for manufactured goods are not competitive. Clearly, where firms possess market power, they can restrict supply and thereby keep price above the competitive equilibrium. Similarly, over the long run, they can keep prices from falling as technology reduces costs, and thus retain the benefits flowing from new technology, benefits that in competitive industries are passed on to consumers.

Indeed, as the following quote highlights, Singer (1950, pp. 477-8) explicitly rejects the idea that the trend in the terms of trade for primary products simply reflects a decline in their production costs relative to those for manufactured goods, proposing instead that market power produces an asymmetry in the distributions of the benefits of technological progress favoring the producers of manufactured goods:

The possibility that these changing price relations simply reflect relative changes in the real costs of manufactured exports of the industrialized countries to those of food and primary materials of the underdeveloped countries can be dismissed. All the evidence is that productivity has increased if anything less fast in the production of food and raw materials, even in the industrialized countries but most certainly in the underdeveloped countries, than has productivity in the manufacturing industries of the industrialized countries. ...

Dismissing, then, changes in productivity as a governing factor in changing terms of trade, the following explanation presents itself: the fruits of technical progress may be distributed either to producers (in the form of rising incomes) or to consumers (in the form of lower prices). In the case of manufactured commodities produced in more developed countries, the former method, i.e., distribution to producers through higher incomes, was much more important relatively to the second method, while the second method prevailed more in the case of food and raw material production in the underdeveloped countries.

This quote raises two important questions. First, to what extent do firms producing goods traded in world markets actually possess market power? Or, more specifically, is there a systematic tendency for the markets for primary products, but not those of other traded goods, to be competitive? And second, where markets are not 
competitive, is there still a tendency for prices and costs to move up and down together, or are they as Singer contends independent of each other?

Both Prebisch and Singer were greatly influenced by the world economic situation in the late 1940s, the period when they were conducting the research and developing the insights reflected in their two articles. At that time, the industrialized world was largely confined to North America, Europe, and Japan, and both Europe and Japan were struggling to recover from the devastation of World War II. So the United States was by far the dominant industrial power, and many of its concentrated industries, such as the automobile and industrial equipment industries, may well have possessed market power.

The economic recovery of first Europe and then Japan, coupled with the more recent industrialization of Korea, Taiwan, Singapore, and now China and India, have completely altered the world economic scene. Today, globalization is widely recognized by both its proponents and opponents as a major force reshaping the world. Aside from a few primary products, such as diamonds and oil, it is hard to identify goods whose producers might possess market power, and who for long could prevent the benefits of new technology from flowing to consumers in the form of lower prices. When we look at goods with rapidly declining prices, we typically find products where innovation and new technology are driving production costs down. They include manufactured goods, such as computers and other electronic equipment, as well as aluminum and other primary products at least over the long run. Goods with constant or rising prices tend to have constant or rising costs, largely because they are labor intensive and for this or other reasons more impervious to the downward pressure on costs imposed by new technology.

Moreover, even in those remaining pockets of the economy where firms do possess some market power, prices may still follow trends in production costs. This is the case, for example, where producers set prices on the basis of costs plus some designated markup. We also know from microeconomic theory that pure monopolists and dominant firms with fringe competitors will expand output up to the point where their marginal costs just equal their marginal revenue. As a result, if marginal costs fall they have an incentive to reduce their prices. In the Cournot model of oligopoly pricing, where firms assume their competitors' output is fixed, it can be shown that the ratio of the difference between the market price and the weighted average industry marginal costs to the market price equals the ratio of market concentration (measured by the Herfindahl-Hirshman index) to the elasticity of market demand. So a fall in the average industry marginal costs produces a reduction in the market price assuming the market concentration and the elasticity of demand do not change (Scherer and Ross, 1990, p. 200).

Specifically with respect to producer prices for metals and other mineral commodities, Crowson (2008, p. 210), who served for many years as the Chief Economist for RioTinto, notes:

Where producers set prices they tend to keep them fixed for long periods. They often set them not by reference to marginal costs 
whether their own or those of the industry, but to some form of average cost. Prices change in response to clear external stimuli, like movements in the costs of major raw materials such as crude oil, or in exchange rates.... Thus, for many years there was an observable relationship between the list prices for nickel cathode put out by the major producer, International Nickel Co (Inco), and its average costs. ... .

So even where producers possess market power, there are both good conceptual reasons and empirical evidence suggesting that prices and costs often move together.

\section{Policy Implications for Countries Exporting Primary Products}

Although the debate over the long-run trend in the terms of trade of primary products remains unresolved, it is still worth considering the implications of a declining trend for countries that produce and export these products. This is especially so since the implications are not as self-evident or clear as Prebisch, Singer, and many others suggest.

It is true that falling terms of trade mean that countries exporting primary products must over time offer an ever bigger basket of export products (that is, more and more iron ore, coffee, or wheat) for a given basket of (non-primary) imported goods. As a result, it is frequently presumed that the benefits these countries derive from trade are declining, and that they would be better off diversifying away from primary product production. Economists, however, have long recognized that the simple barter terms of trade, given by the weighted prices of exports over imports, can be misleading in this regard.

The reason for this is that ultimately the welfare of a country depends on the wealth, or what economists call rents, that it generates and retains. The production of goods and services produces rents in two ways. First, it creates consumer surplus, which is the difference between what consumers would be willing to pay for a good and what they actually have to pay. It is measured by the area under the demand curve and above the market price. For example, Figure 3 shows a long-run world demand curve $\left(\mathrm{DD}_{\mathrm{w}}\right)$ and world supply curve $\left(\mathrm{SS}_{\mathrm{w}}\right)$ for a good, such as copper. The equilibrium price is $\mathrm{P}_{\mathrm{e}}$ and output $\mathrm{Q}_{\mathrm{e}}$. The area $\mathrm{ABP}_{\mathrm{e}}$ represents the total (global) consumer surplus generated by the production of copper.

Second, the production of goods and services also creates producer surplus, which for any given product is the difference between the price at which producers would be willing to supply the good and the actual market price. It is measured by the area below the market price that lies above the supply curve. In competitive markets, where the supply curve reflects the industry marginal cost curve, producer surplus is the difference

\footnotetext{
${ }^{5}$ For a discussion of the various ways that economists have modified the simple barter terms of trade in an attempt to overcome its shortcomings, see Meier (1968).
} 
between the total production costs and the total revenues of the producing firms. In Figure 3, total (global) producer surplus is given by the $\mathrm{P}_{\mathrm{e}} \mathrm{BC}$.

Now, if a developing country produces a primary product, such as copper, its long-run supply curve might look like $\mathrm{SS}_{\mathrm{c}}$ in Figure 3. In this case, its producer surplus, which would constitute a part of the total producer surplus, would be given by the triangle $\mathrm{P}_{\mathrm{e}} \mathrm{DE}$. If this country's domestic consumption of copper is small, the wealth it receives from the copper industry would be determined largely by its producer surplus.

Everything else being equal, any tendency for the market price of copper to decline over time reduces the producer surplus and hence the wealth that such a country realizes from mining and exporting copper. On the other hand, for those countries exporting products whose price is rising, just the opposite is the case. Since the real prices of numerous primary products have been declining over the long run, many maintain the benefits that countries exporting primary products realize in the form of producer surplus are also falling. As a result, like Prebisch and Singer, they believe that these countries would be better off if they diversified into the production of goods with rising prices. ${ }^{6}$

Of course, such a strategy if adopted by all, or even by many, countries would be self-defeating. As countries reduced their output of primary products and moved their labor and other resources into the production of manufactured goods and services, the prices of the former would rise and those of the latter fall, reversing any decline in the terms of trade of primary products.

More importantly, however, this policy recommendation depends critical on the assumption that everything else remains the same as the terms of trade of primary products fall. However, as we have seen, prices and production costs normally move together. In the long run price trends for most products are driven largely or entirely by shifts in their supply curves, which in turn reflect changes in production costs arising from new technology and other factors. In the short run when demand is strong and output is at or near capacity, shifts in the demand curve largely drive prices, which in turn affect production costs and the supply curve. In the short run when demand is down, prices and costs also move together, though cause and effect can flow in either direction

\footnotetext{
${ }^{6} \mathrm{~A}$ recent example is Harvey and others (2010). This interesting study, as noted earlier, uses new timeseries techniques and prices for 25 commodities spanning four centuries. After finding significant downward long-run trends for 11 of the 25 commodities, it then proceeds in the concluding section to consider the policy implications, stating: "Primary commodity production contributes a significant fraction of the export volume of many developing countries. Given this context, the time-series properties of such prices relative to manufactured goods, have important policy implications. A negative trend, for example, in the relative price of a country's main export commodity indicates the need to consider diversifying the export mix." Somewhat surprisingly, the study reaches this conclusion despite the fact that earlier in footnote 1 it points out: "Of course, economic decision making should account for costs as well as prices. For instance, it is quite possible that a long-run decline in prices is compensated by a long-run decline in marginal production costs." This important point seems to have been overlooked in the concluding section of this article as well as in other studies examining long-run trends in primary commodity prices.
} 
in this situation. For these reasons, to assume that the production costs of primary products remain unchanged while their prices fall is simply untenable.

For an individual country, the net effect of declining prices and costs may be positive, neutral, or negative depending on whether the downward shift in its costs and supply curve is sufficient to offset the reduction in its total revenues arising from the decline in price. In short, if its costs are falling faster than the market price, the wealth it realizes in the form of producer surplus is increasing. In this situation, shifting out of primary product production will slow wealth creation and presumably the pace of economic development.

On the other hand, if prices are falling faster than its costs, then the wealth a country realizes in the form of producer surplus is declining. The reason for this, however, is not the decline in price and the resulting deterioration in the country's terms of trade, but rather the country's failure to keep up with its competitors in terms of reducing its production costs. This may reflect a loss of comparative advantage in the production of primary products. If so, it is for this reason, and not the declining terms of trade, that it should be moving out of the production of primary products.

Finally, it should be noted that rising export prices are not necessarily good for producing countries, since rising prices are normally accompanied by higher production costs. Countries producing such goods may not find their producer surplus increasing over time. Whether this is, or is not, the case depends on how rapidly their costs are increasing relative to those of their competitors, and in turn relative to the rise in the market price.

\section{Conclusions}

The terms of trade debate initiated by Prebisch and Singer over 60 years ago continues to this day, and is unlikely to be resolved soon. For a country exporting primary products, however, whether the terms of trade for primary products are falling, stationary, or rising by itself has little importance. Long-run trends in the real prices of most goods and services largely reflect shifts in their market supply curves and in turn production costs. For somewhat different reasons, prices and costs also tend to move together over the short run.

If the price of a primary product is falling but a country's production costs are falling more, then the wealth the country realizes in the form of producer surplus is rising, increasing the benefits it receives from its production and trade. Alternatively, if price is rising but a country's costs are rising more, the benefits from production and trade are falling despite the rising price.

As a result, even if the terms of trade of primary products are falling, to suggest that countries should diversify away from their production, as Prebisch, Singer, and others over the years have done, makes little sense. Indeed, it may very well be 
counterproductive, encouraging countries to abandon what is a promising path to faster economic development.

\section{References}

Bloch, H., Dockery, A.M., MacDonald, G., Sapsford, D., and C.W. Morgan, 2002, Trends in the prices of primary commodities over the $20^{\text {th }}$ century, Curtin University of Technology, Business School Working Paper 02.06.

Bloch, H., and D. Sapsford, 1991, Postwar movements in prices of primary products and manufactured goods, Journal of Post-Keynesian Economics, Winter, 14, 2, pp. 249-266.

Bloch, H., and D. Sapsford, 1996, Trends in the international terms of trade between primary producers and manufacturers, Journal of International Development, 8, 1 , pp. 53-67

Bloch, H., and D. Sapsford, 1997, Some estimates of Prebisch and Singer effects on the terms of trade between primary producers and manufacturers, World Development, 25, 11, pp. 1873-1884.

Bloch, H., and D. Sapsford, 2000, Whither the terms of trade?, Cambridge Journal of Economics, 24, 4, pp. 461-481.

Boskin, M.J., E.R. Dulberger, R.J. Gordon, Z. Grilliches, and D.W. Jorgenson, 1998, Consumer prices, the consumer price index, and the cost of living, Journal of Economic Perspectives, 12, 1, pp. 3-26.

Crowson, P., 2008, Mining Unearth, London: Aspermont UK.

Cuddington, J.T., 1992, Long-run trends in 26 primary commodity prices: A disaggregated look at the Prebisch-Singer hypothesis, Journal of Development Economics, 39, pp. 207-227.

Cuddington, J.T., R. Ludema, and S.A. Jayasuriya, 2007, Prebisch-Singer redux, in D. Lederman and W.F. Maloney, eds., Natural Resources: Neither Curse Nor Destiny, Palo Alto, CA: Stanford University Press; and Washington, DC: The World Bank, pp. 103-140.

Davis, G.A., and J.E. Tilton, 2005, The resource curse, Natural Resources Forum, 29, pp. 233-242. 
Fernandez, V., 2012, Trends in real commodity prices: How real is real? Resources Policy, 37, pp. 30-47.

Flores, C.A., R.A. Picón, and G.P. Rodríguez, 2011, Copper prices and production costs, unpublished paper, Santiago, Chile: Catholic University of Chile, Department of Mining Engineering. Available upon request from the author.

Grilli, E., and M.C. Yang, 1988, Primary commodity prices, manufactured goods prices and the terms of trade of developing countries: What the long run shows, The World Bank Economic Review, 2, pp. 1-47.

Hadass, Y.S., and J.G. Williamson, 2002, Terms of trade shocks and economic performance 1870-1940, Prebisch and Singer revisited, working paper, Harvard University. An earlier version of this paper is available from www.nber.org/papers/W8188 as a NBER working paper.

Harvey, D., N. Kellard, J. Madsen, and M. Wohar, 2010, The Prebisch-Singer hypothesis: Four centuries of evidence, The Review of Economics and Statistics, 92, 2, pp. 367-377.

León, J., and R. Soto, 1997, Structural breaks and long-run trends in commodity prices, Journal of International Development, 9, 3, pp. 347-366.

McAllister, R., G. Hyun, and R. Gelman, 2011, The relationship between copper prices and costs, unpublished paper, Golden, CO: Colorado School of Mines, Division of Economics and Business. Available upon request from the author.

Meier, G.M., 1968, The International Economics of Development, New York: Harper \& Row.

Prebisch, R., 1950, The Economic Development of Latin American and its Principal Problems, United Nations, Economic and Social Council, Economic Commission for Latin America, reprinted in Economic Bulletin for Latin America, 1961, 7, 1, pp. 1-22.

Scherer, F.M., and D. Ross, 1990, Industrial Market Structure and Economic Performance, 3rd edition, Boston, MA: Houghton Mifflin.

Schultze, C.L., 2002, The consumer price index: Conceptual issues and practical suggestions, Journal of Economic Perspectives, 17, 1, pp. 3-22.

Singer, H.W., 1950, The distribution of gains between investing and borrowing countries, American Economic Review, May, 40, 2, pp. 472-485.

Spraos, J., 1980, The statistical debate on the net barter terms of trade between primary commodities and manufactures, The Economic Journal, 90, 357, pp. 107-128. 
Stevens, P., 2003, Resource impact: Curse or Blessing? A literature survey, The Journal of Energy Literature, 9, pp. 3-42.

Svedberg, P, and J.E. Tilton, 2006, The real, real price of nonrenewable resources: Copper 1870-2000, World Development, 34, 3, pp. 501-519.

Tilton, J.E., 1992, Economics of the mineral industries, in H.L. Hartman, ed., SME Mining Engineering Handbook, $2^{\text {nd }}$ edition, Littleton, CO: SME, pp. 47-62.

Tilton, J.E., 2003, On Borrowed Time? Washington, DC: Resources for the Future. 
Figure 1. Changes in Short-Run Market Prices Due to Shifts in the Supply and Demand Curves

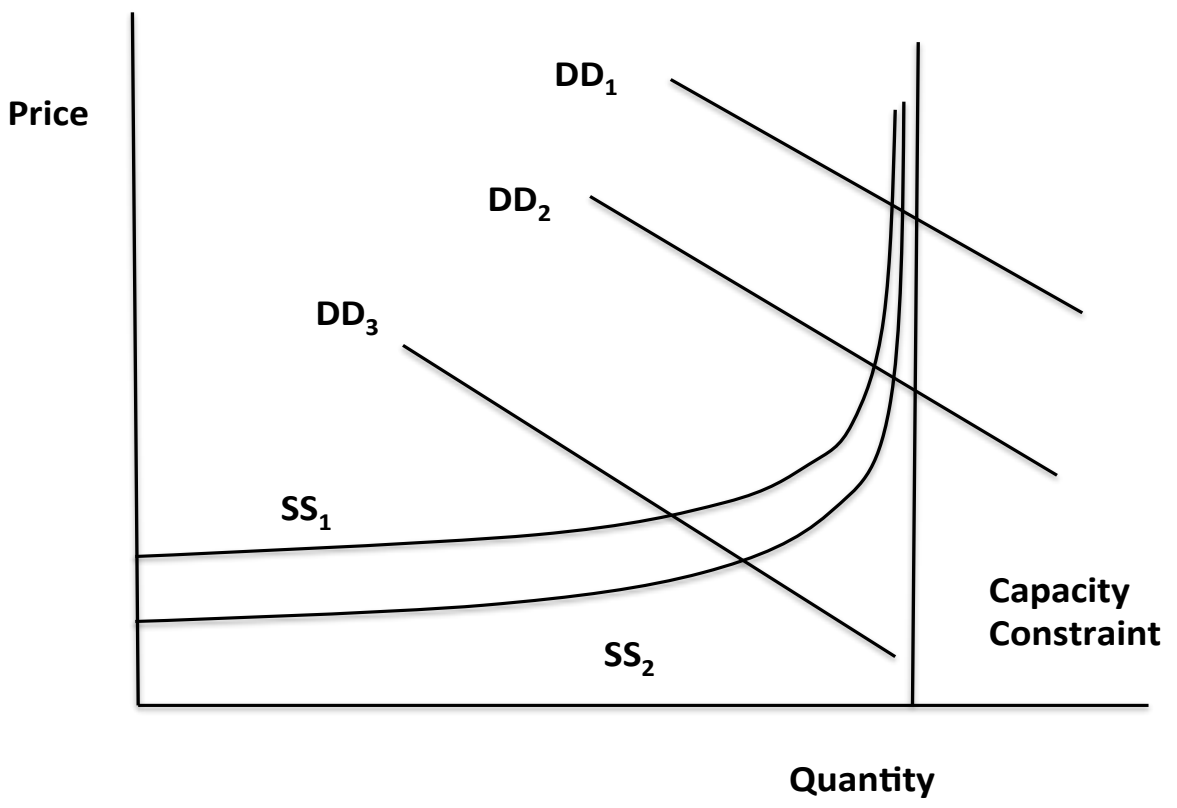


Figure 2. Changes in Long-Run Market Prices

Due to Shifts in the Demand Curve

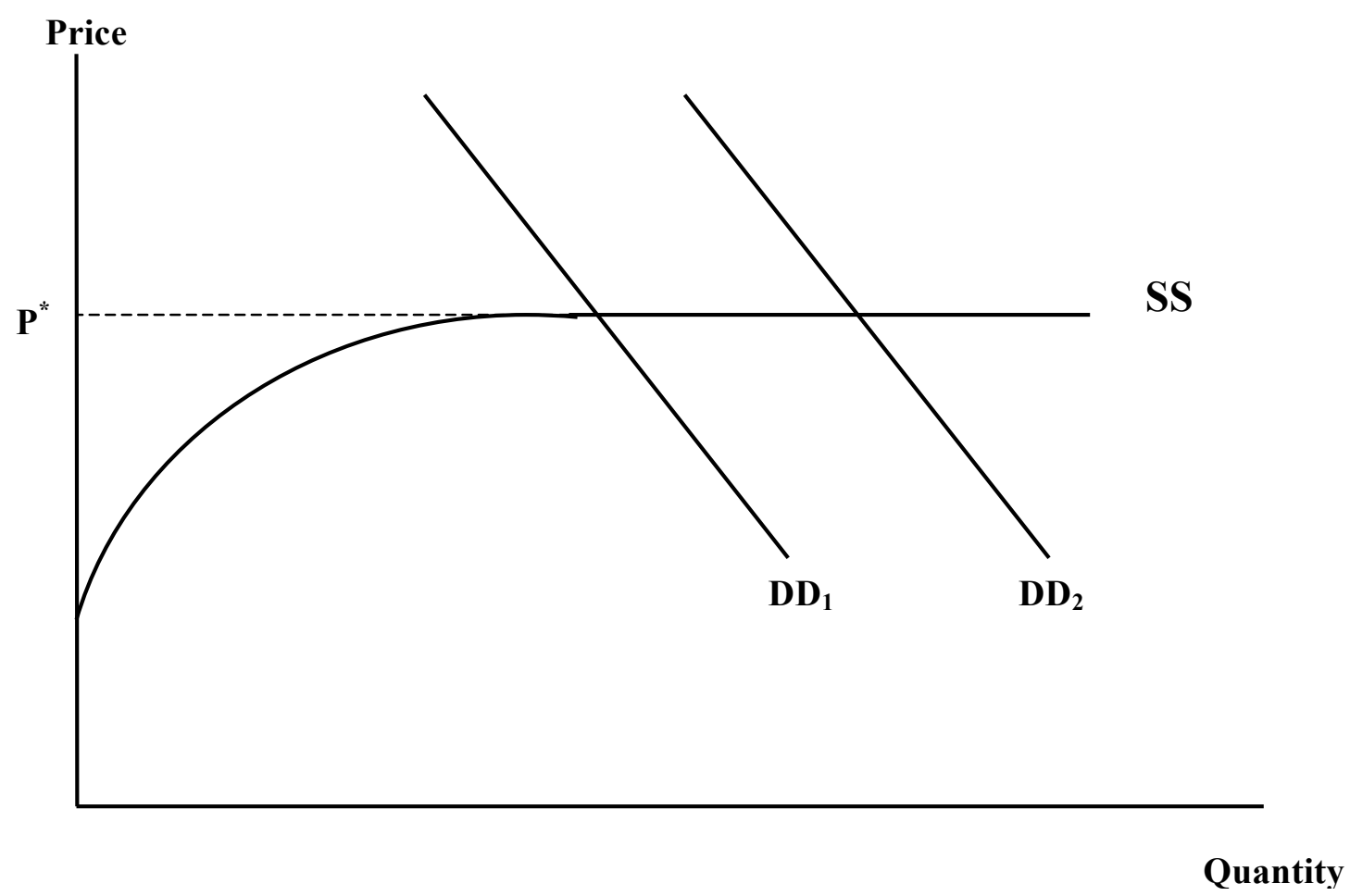

Figure 3. Consumer Surplus and Producer Surplus

Created by the Production of a Primary Product

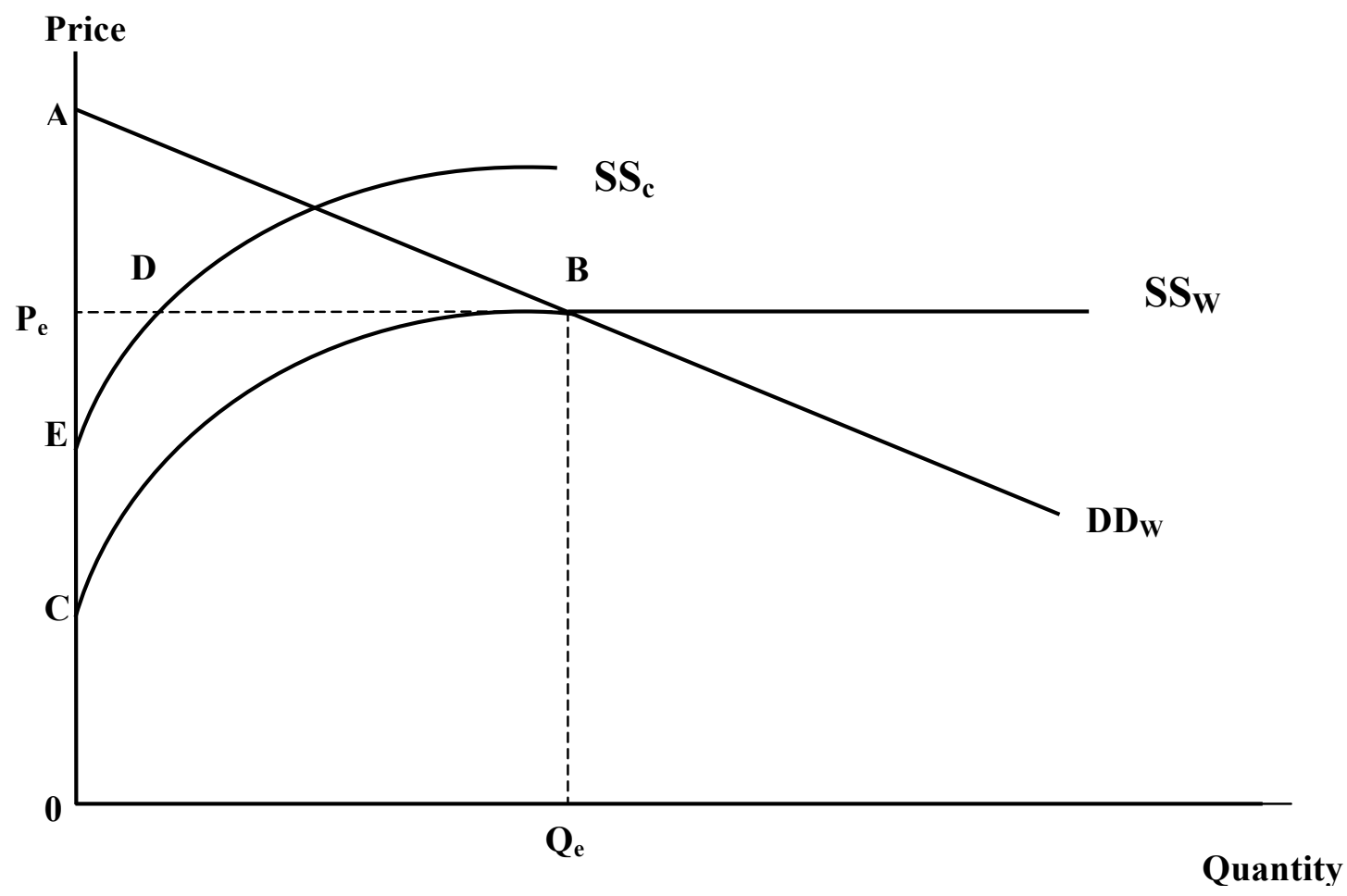

